\title{
Evaluation of environmental impacts at the Aluízio Campos complex, Paraíba, Brazil
}

\begin{abstract}
The city of Campina Grande-PB is lacking preserved urban areas, particularly ecological reserves. The conservation of these areas provides an improvement in air quality in cities, in addition to improving the quality of life. Therefore, this study aimed to analyze the environmental impacts, in order to support the management of natural resources, in Aluízio Campos Complex in the city of Campina Grande - PB. This research is characterized as exploratory, outlined the method of observation and qualitative, quantitative, descriptive and interdisciplinary analysis of nature. As a tool for the identification and assessment of environmental impacts used the Leopold matrix adapted and remote sensing tools. An expressive quantitative of fauna resources was identified, and the ecological importance of the area was recorded with representatives of the most diverse zoological groups (mammals, reptiles, amphibians, birds and invertebrates); found too that the area is anthropic, with various vegetation types: area off quarry; vegetable remnants of large, grazing area, among others. Therefore, it is recommended actions for continuous and permanent environmental education with residents of the area and the surroundings; Regarding ecological integrity in the Aluizio Campos Complex, a high degree of degradation was observed, with remnants of vegetation from the ecotone caatinga and Atlantic forest.
\end{abstract}

Keywords: Human Disturbance; Natural Resources; Environmental Degradation; Leopold Matrix; Remote Sensing.

\section{Avaliação de impactos ambientais no complexo Aluízio Campos, Paraíba, Brasil}

\begin{abstract}
A cidade de Campina Grande-PB carece de áreas urbanas preservadas, principalmente reservas ecológicas. A conservação dessas áreas proporciona uma melhoria na qualidade do ar nas cidades, além de melhorar a qualidade de vida. Portanto, este estudo teve como objetivo analisar os impactos ambientais, a fim de subsidiar a gestão de recursos naturais, no Complexo Aluízio Campos, no município de Campina Grande - PB. Esta pesquisa caracteriza-se como exploratória, delineou o método de observação e análise qualitativa, quantitativa, descritiva e interdisciplinar da natureza. Como ferramenta para a identificação e avaliação de impactos ambientais, utilizou-se as ferramentas adaptadas e de sensoriamento remoto da matriz de Leopold. Um expressivo quantitativo de recursos da fauna foi identificado, e a importância ecológica da área foi registrada com representantes dos mais diversos grupos zoológicos (mamíferos, répteis, anfíbios, aves e invertebrados); também descobriu que a área é antrópica, com vários tipos de vegetação: área de pedreira; restos vegetais de grande área de pastagem, entre outros. Portanto, recomenda-se ações de educação ambiental continuada e permanente com moradores da região e do entorno; Em relação à integridade ecológica no Complexo Aluízio Campos, observou-se alto grau de degradação, com remanescentes de vegetação da caatinga ecótona e da mata atlântica.
\end{abstract}

Palavras-chave: Perturbação Humana; Recursos Naturais; Degradação Ambiental; Leopold Matrix; Sensoriamento Remoto.

Topic: Sistemas de Gestão Ambiental

Reviewed anonymously in the process of blind peer.

Joaci dos Santos Cerqueira (iD

Universidade Federal de Campina Grande, Brasil

http://lattes.cnpq.br/4470582307237189

http://orcid.org/0000-0002-0109-3849

cerq2006@gmail.com

Helder Neves de Albuquerque (iib

Universidade São Marcos, Brasil

http://lattes.cnpq.br/1316763030688970

http://orcid.org/0000-0002-5076-3060

helderbiologo@gmail.com

Ênio Pereira de Souza (1D)

Universidade de São Paulo, Brasil

http://lattes.cnpq.br/7752212981363912

http://orcid.org/0000-0001-6154-398X

esouza@dca.ufcg.edu.br

6

DOI: 10.6008/SPC2179-6858.2017.004.0021
Received: 19/07/2017

Approved: 20/10/2017
Referencing this:

CERQUEIRA, J. S.; ALBUQUERQUE, H. N.; SOUZA, E. P.. Evaluation of environmental impacts at the Aluízio Campos complex, Paraíba, Brazil. Revista Ibero-Americana de Ciências Ambientais, v.8, n.4, p.255-267, 2017. DOI: http://doi.org/10.6008/SPC2179-6858.2017.004.0021 


\section{INTRODUCTION}

The development of human society has produced many advances, but also some catastrophic aspects. In this contradiction, it induces the human to search for postures and a permanent search for results, efficiency and accumulation. According to Jacobi (2006), the unbridled exploitation of natural resources in the current model of exploitation puts at risk the physical conditions of life on Earth for humanity, as the capitalist economy demands and practices a level and type of production that are environmentally unsustainable.

With the historical formation of human rights, it is demonstrated the need for effective protection of the environment, seeking to achieve a more systematic use of its natural resources and structure a control more effective of the use of natural resources by the resident population, identifying some points that appear when intensified human degradations and shortages of natural resources (BENATTI et al., 2003; FALEIROS JÚNIOR et al., 2012).

In Paraíba, the process of occupation of the territory originated as a function of the sugar production, which specifically benefited the cities that were close to the fields of sugar cane cultivation. The state of Paraíba is currently lacking in preserved urban areas, particularly ecological reserves. The conservation of these areas provides an improvement in the air quality of cities, as well as improving people's quality of life (SILVA, 2004; NÓBREGA, 2013). Located in the Agreste region, Campina Grande is the second most important city in the state of Paraíba, and its occupation was due to the decline of the sugarcane agroindustry, from the XVII century and until the sixties it was the most important city of the State (SILVA, 2004).

The Aluízio Campos Complex (CAC) - Campina Grande - PB (Brazil), preserves remnants of natural resources with a native forest rich in rare species of transition ecosystem Atlantic-Caatinga Forest and fauna that hosts birds, mammals, reptiles, amphibians, fish, Invertebrates and microorganisms little studied (CERQUEIRA et al., 2011). In the CAC area there are economic agricultural activities of dairy cattle and fattening considered outside sustainable activities. It is also verified that, in the area, there is high-voltage electrical network, railroad, gas pipeline, quarries and aircraft traffic, in addition, evidence of predatory hunting and fishing, among other tensions that reduce the system's resilience (ALVES et al., 2010; LOPES, 2010; CARVALHO et al., 2011; FERREIRA, 2011).

Thus, it is important to study this system from the point of view of anthropic impacts and ecological integrity, thus contributing, with the management of natural resources in the region, towards proper management of recovery. The relevance of this work refers to knowing, conserving and recovering the environment of the Aluízio Campos Complex due to the urban growth of Campina Grande/PB.

Therefore, this study is of great importance, not only due to the lack of studies and actions aimed at the conservation and recovery of biodiversity and ecosystem services, but also to the survival of the local community, with satisfactory levels of sustainability. In this context, the objective was to analyze the environmental impacts, with the purpose of subsidizing the management of its natural resources, in the Aluízio Campos Complex (CAC), in the city of Campina Grande-PB, besides identifying and evaluating the main anthropic impacts. 


\section{MATERIAL AND METHODS}

\section{Location and description of the study area}

The present study was carried out at the Aluízio Campos Complex (CAC), in Campina GrandePB/Brazil, located120 km from the capital (latitude 7015'33'83 "S and longitude 3552'38.87" W, average elevation: $485 \mathrm{~m}$ ). For study and better identification, the CAC was highlighted in red on the map (figure 1). The study area is limited to the following points of Campina Grande: (to the north) urban sector of Campina Grande, (to the South) BR-104/South, (to the West) João Suassuna President Airport (to the East) rural properties of Brazil Bank (ALBUQUERQUE et al., 2013).

In relation to the physical aspects, the studied area has a climate according to the classification of Köppen, type As' (hot and humid) with average annual temperatures between 22 to 26 으. The average precipitation is $700 \mathrm{~mm}$ annually, with rains from April to September. The relative humidity of the air is $80 \%$ (EMBRAPA, 1972; FRANCISCO et al., 2010). The relief is strong, undulating and hilly, with soils of low agricultural ability, with moderate to strong natural fertility deficiency, strong to very strong, water deficiency and strong susceptibility to erosion (SANTOS et al., 2006).

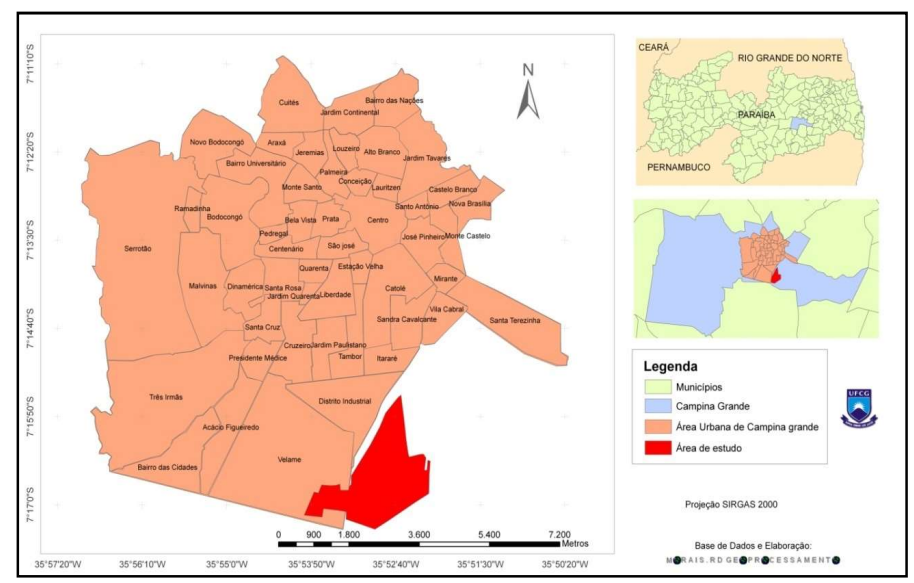

Figure 1: Aluízio Campos Complex highlighted in red.

\section{Methodological procedure}

This research was exploratory delineated with the method of observation and analysis of qualitative, quantitative, descriptive and interdisciplinary nature. The time cut was in the reading of the last ten years. The data were collected from January to December 2015. The materials used included: data and orbital images, planimetric data (TM/LANDSAT-5 satellites) available by the National Institute of Space Research INPE (2007), GPS Garmin Extrex Vista HCx, software such as: Microsoft Excel 2013, ArcGis 2011 and Erdas Imagine 2010.

\section{Matrix for identification and evaluation of anthropogenic impacts}

The records of the anthropic impacts were identified through in situ observation, using a Matrix (LEOPOLD et al., 1971), adapted to better qualify and quantify the anthropic impacts. In the evaluation of anthropic and environmental impacts, the Expert Judgment Method with the aid of a specialist system and a 
computer program (SÁNCHEZ, 2013). To the valuation of the impacts, the evaluation of Sanchez (2013) with adaptations was used as described in chart 1 , below. Regarding the parameters for the characterization and the evaluation of the impacts, the aspects and the observations arranged in chart 2 were considered, with adaptations for better understanding.

Chart 1: Valuation of the environmental impacts, adapted.

\begin{tabular}{|l|l|l|l|}
\hline $\begin{array}{l}\text { Total Impact: TI = N. (F+C+T+D+R+P+M+I) } \\
\text { Valuation of Impact }\end{array}$ & Negative (-1) & Neutral (0) \\
\hline Nature & Direct (3) & Indirect (2) & Positive (+1) \\
\hline Form & Regional (3) & Local (2) & Undefined (0) \\
\hline Comprehensiveness & Short Term (3) & Mid-Term (2) \\
\hline Temporality & Permanent (3) & Temporary (2) & Long-Term (1) \\
\hline Duration & Irreversible (3) & Partial (2) & Ciclic (1) \\
\hline Reversibility & High (3) & Mid (2) & Reversible (1) \\
\hline Probability & Big (3) & Mid (2) \\
\hline Magnitude & Significant (3) & Moderate (2) & Little (1) \\
\hline Importance & & & Not Significant (1) \\
\hline
\end{tabular}

Source: Sánchez (2013).

Chart 2: Parameters for environmental impact assessment, adapted.

\begin{tabular}{|c|c|}
\hline ASPECTS & OBSERVATION \\
\hline Nature & Indicates when impact influences the environment. \\
\hline Form & $\begin{array}{l}\text { How does the impact occur, arising from an action of the enterprise, or is it an impact arising from } \\
\text { another, or other, impacts generated directly or indirectly by it. }\end{array}$ \\
\hline Comprehensiveness & $\begin{array}{c}\text { It indicates the impacts whose effects are felt in or that can affect broader geographical areas, } \\
\text { characterizing themselves as impacts. It is considered as a local effect to the one that is restricted to the } \\
\text { area directly affected of the enterprise and, regional, that which is reflected in the area of direct } \\
\text { influence. }\end{array}$ \\
\hline Temporality & It differentiates impacts according to manifestation immediately after the impact action. \\
\hline Duration & Criterion indicating the duration of the impact. \\
\hline Reversibility & It classifies the impacts according to the manifestation of its effects. \\
\hline Probability & $\begin{array}{l}\text { The probability or frequency that an impact can occur almost certainly and constant throughout the } \\
\text { activity. }\end{array}$ \\
\hline Magnitude & $\begin{array}{l}\text { Refers to the degree of incidence and interference of an impact on the environmental factor, in relation } \\
\text { to the universe of this environmental factor. The magnitude of an impact is therefore treated exclusively } \\
\text { in relation to the environmental factor in question, regardless of its importance because it affects other } \\
\text { environmental factors. }\end{array}$ \\
\hline Importance & $\begin{array}{c}\text { Indicates the importance or significance of the impact in relation to its interference with the } \\
\text { environment. }\end{array}$ \\
\hline
\end{tabular}

Source: Sánchez (2013).

\section{Geoprocessing system}

For the treatment of satellite images, the software Erdas 2010 and ArcGis 2011 of the Federal University of Campina Grande (UFCG) were used. In relation to the pre-processing and/or digital processing of satellite images, images of the Landsat 5 satellite were used. The images were acquired online, through the National Institute of Space Research (INPE, 2013). The scenes used from the Landsat 5 satellite captured by the Thematic Mapper (TM) sensor were those captured on July 10, 1989 and September 28, 2007. For overlapping information, the stacking utilized the sensor bands 1, 2, 3, 4, 5 and 7, in view of the band 6 consisting of information regarding surface temperature. The cutout of the selected areas was based on the collection of points of GPS (Global Positioning System). 


\section{RESULTS AND DISCUSSION}

This approach allowed to evaluate the anthropic impacts to better manage natural resources, present in the CAC, where it was possible to describe the main negative environmental impacts and the ecological integrity of the area, evidencing that this study is characterized as unpublished, revealing primordial conditions and circumstances For further studies regarding the recovery of degraded areas and support for future generations to know the environmental history of the peri-urban areas of the city of Campina Grande/PB.

\section{Leopold's Matrix adapted}

The qualification of the main environmental impacts present in the Aluízio Campos Complex are shown in figure 2 , showing the estimation and prognosis of loss of the local environment. Actions on the horizontal axis (landscape modification, land transformation and constructions, resource extraction, processing, soil change and resource renewal), which have generated impacts to the composite factors on the vertical axis (physical and chemical characteristics, biological and Cultural factors). Therefore, the existing environmental conditions were potentially affected.

Negative impacts were considered with High valuation for: soils, trees, shrubs, grasses and birds; Mid for: surface, quality, erosion, compaction, reptiles, meso and macrofauna, mammals, agriculture, hunting and fishing; Neutral or positive impacts to: quality (gases, particles) and housing. The presence of exotic flora in the Aluízio Campos Complex, such as Prosopis juliflora (Sw) DC (algarobeira) and Euphorbia tirucalli (avelós) can be observed. Of the plants introduced in the Caatinga, and that have adapted well to the region, stand out the Algaroba, the Palma, the Avelós and the Leucena. As for Avelós (Euphorbia tirucalli), it originated in Africa and was introduced in Brazil throughout its colonization (SINOKI et al., 2011).

In relation to the species Prosopis juliflora (Algaroba), the great abundance of individuals and the inexpressive presence of native species demonstrate the high dispersion and exclusion capacity of the invading taxa in Paraíba. Thus, there is a need for control of the invasive species in the Caatinga biome to preserve and perpetuate the native species (ANDRADE et al., 2010). The emergence of invasive species represents a disturbance of the organization of ecosystems that can even increase their entropy, causing direct impacts to insects and microorganisms (SILVA NETO, 2008).

In relation to the impacts, modification of the landscape, referring to the creation of domesticated animals, such as: cattle and dogs, the following impacts were predicted as negative: high for, soils, compaction, trees, shrubs, grasses, birds, meso and macrofauna and mammals; mid to, surface, water quality, quality (gases, particles), erosion, reptiles, agriculture and hunting; and qualified as neutral or positive impact for the items, housing and fishery.

On soil compaction, due to the action of dairy cattle, Miguel et al. (2009) points out that the rate of infiltration of water in the soil, presents a structure of spatial dependence, which increases as a function of the intensity of trampling, which indicates the occurrence of compaction of the soil, due to cattle trampling. The impacts related to the transformation of the land and constructions relative to urbanization, were 
predicted as negative and high all items, except the dwelling item that was considered as positive or neutral. In the Aluízio Campos Complex, nine residential dwellings are present, which are isolated, and some do not have basic sanitation, even with absence of electricity and treated water. In addition, the Residents realize the flora and fauna resources of the place. In the surroundings of the CAC there are a large number of residences, which are part of the neighborhoods, Ligeiro, municipality of Queimadas/PB (south), Velame (west) and Itarare (south), among other constructions such as industries, warehouses, airport, etc.

According to Mucelin et al. (2008), the population growth, the consequent urban territorial expansion and the expansion of the system of production and industrial consumption have contributed directly to aggravate the environmental conditions, especially the urban scenario. The use and occupation of land, especially for dwelling, environmental sanitation and occupation of risk areas, as well as the form of occupation of urban spaces in the current capitalist society, perpetuates inequality in access to natural resources (FRACALANZA et al., 2013).

Regarding the impacts on the transformation of the terrain and constructions related to roads, trails, viaducts, bridges, railways, transmission lines and gas pipeline, it is observed that all were qualified as negative, being assigned high value for items, soils, erosion, compression, trees, shrubs, grasses, birds, meso and macrofauna, mammals, dwelling, agriculture and hunting; The items, surface, water quality and quality (gases, particles) of the atmosphere were evaluated as mid impact. The presence of roads, high-voltage transmission lines, railroad, highway, was detected in the Aluízio Campos Complex (CAC). In addition, there is also in the CAC viaduct and gas pipeline.

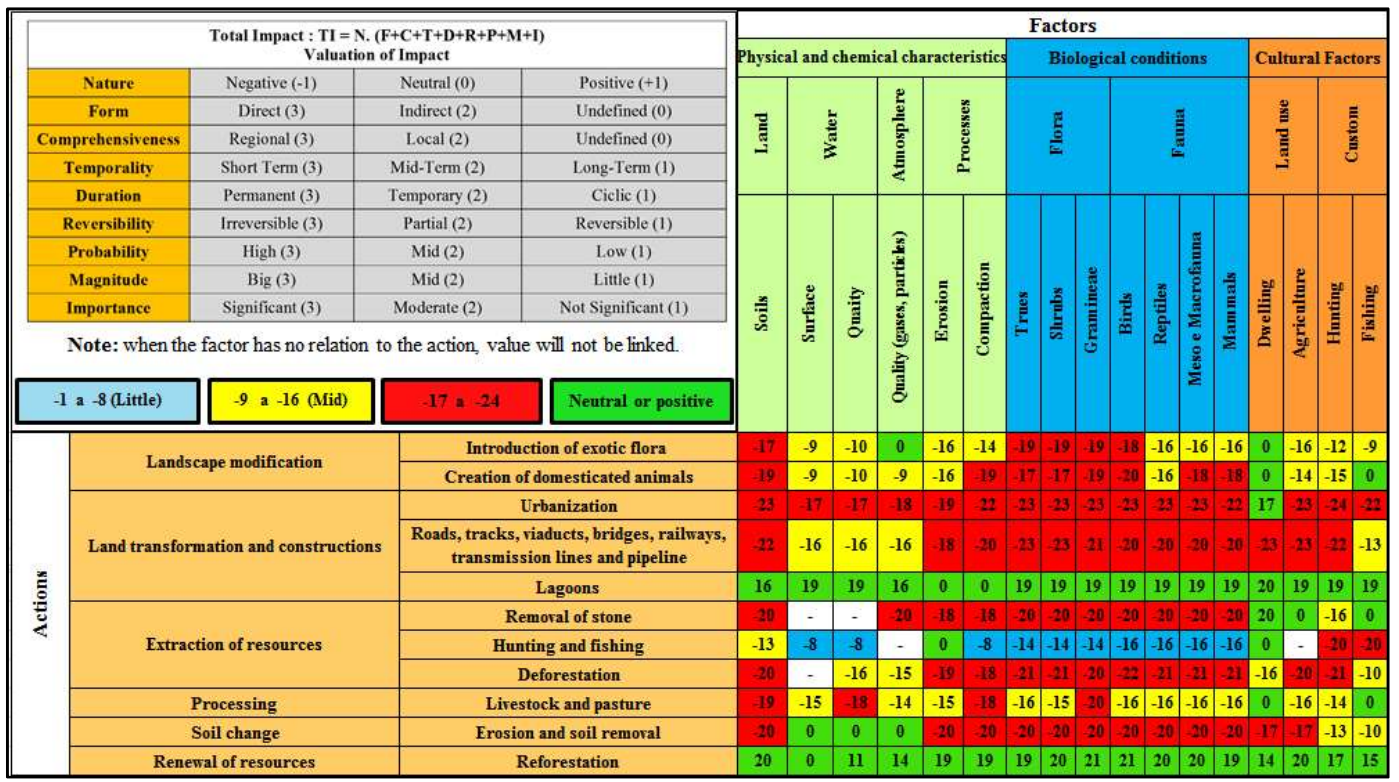

Figure 2: Leopold matrix, adapted factors and actions of the environmental impacts.

In the implementation of roads, according to Sampaio et al. (2009), the main environmental impacts can be defined according to the areas of influence. Concerning the socioeconomic environment, there are conflicts in relation to land occupation, changes in the economic activities of the regions where the highway passes, among others. In relation to the biotic environment, there is a risk of trampling animals, preventing ecological interchange by cutting the areas, reducing vegetation cover and fires in the domain strips. In the 
physical environment occur, soil removal, slope instability, earthworks, degradation of construction site areas, groundwater retraction and silting of natural lands.

Regarding the impacts related to the transformation of the land and constructions, regarding the lagoons, all items were considered as neutral and positive. The presence of little and mid lagoons was found in the Aluízio Campos Complex. Cavalcanti et al. (2001) carried out a survey about the type and quantity of lagoons used by small farmers in the communities of Curaçá, Casa Nova and Jaguarari in the semi-arid region of the State of Bahia, where it was verified that small farmers in this region, face each year problems to supply the water needs of their animals and their families, however, few farmers use dams to store these waters due to the high cost of implantation.

Regarding the extraction of resources, removal of stone, the impacts were classified as negative in the items of the vertical column, with the following valuations $s$ attributed: high impact for soils, quality (gases, particles) of the atmosphere, erosion, compaction, trees, shrubs, grasses, birds, reptiles, meso and macrofauna and mammals; Mid impact on the item cultural factors, relative to custom related hunting; Neutral or positive impact on the land, agriculture and fishing. It was also verified that the items related to surface and water quality had no attributed interactions. It was verified in the Aluízio Campos Complex the existence of a deactivated quarry.

According to Rodrigues et al. (2013), mining activity has considerable impacts on the natural environment. The main impacts identified in the plots are often related to the physical-biotic environment, among which the following stand out: erosion, soil compaction, dust, impacts to flora and fauna due to deforestation from soil decapitation, besides extinction of synergistic species.

Regarding the action related to the extraction of resources in relation to hunting and fishing, included in the Leopold's Matrix adapted, was assessed the negative impacts such as: high for, customs for hunting and fishing; Mid for, soils; Little to, surface and water quality, compaction, trees, shrubs, grasses, birds, reptiles, meso and macrofauna and mammals; neutral or positive for erosion processes and land use for housing. The items focused on the quality (gases, particles) of the atmosphere and the use of land turned to agriculture were not assigned interactions.

CAC, hunting and fishing activities occur frequently. About hunting, it is currently the second major threat that afflicts birds in the Caatinga. This practice is common and widespread throughout the biome, usually related to cultural and economic issues. There is also the practice of capture for breeding, such as cage birds, common not only in small towns or inland villages, but also in large urban centers (ICMBIO, 2011).

The following factors and valuations were predicted as negative for the factors that underwent action of the resource extraction (deforestation): high impact for soil, physical and chemical characteristics on soil, erosion and compaction processes, biological conditions, shrubs, grasses, birds, reptiles, meso and macrofauna and mammals), as well as factors of land use (agriculture) and customs (hunting); mid impact to, water quality and quality (gases, particles) of the atmosphere, dwelling and about the custom involving the fishing. In addition, it was not considered interaction for the water surface item. In the Aluízio Campos Complex, the presence of deforestation is diagnosed. 
Cattle breeding practiced extensively, currently corresponds to a strong concentration of land, mainly after the use of improved pastures and the cultivation of forage plants. Generally, the livestock activity is accompanied by indiscriminate deforestation of the Caatinga that, associated to the natural fragility of this biome, has serious consequences for geotopes and biocenoses (ALVES et al., 2009).

On the processing action, livestock and pasture were rated impacts as, negative and neutral or positive. High negative impact: soils, water quality, compaction processes; Mid negative impact: water surface, atmosphere (gases, particles), erosion, trees, shrubs, birds, reptiles, meso and macrofauna, mammals, agriculture and hunting; Neutral or positive impact: land use for housing and fishing custom. The Aluízio Campos Complex was diagnosed in the presence of livestock raising activity for dairy cattle and fattening cattle.

According to Galharte et al. (2010), activities, agriculture and livestock are generating of waste and environmental impacts. Measures to remediate environmental impacts are necessary to achieve sustainability and protection of ecosystems. Concerning the factors that underwent interactions, soil alteration, erosion and soil removal, the following values were attributed: high negative impact on soils, erosion processes, compaction, biological conditions of fauna and flora, and cultural factors for land use; mid negative impact on cultural factors related to customs (hunting and fishing); neutral or positive impact for the items facing the surface and water quality and also for the quality (gases, particles) of the atmosphere. In the CAC is erosive processes of the soil and area that underwent soil removal (decapitated area).

Impacts caused by erosion are seen in crops (plant population and plant damage), soil productivity (changing soil properties), generating production costs (loss of nutrients and organic matter), as well as causing pollution and silting (DANTAS et al., 2008). On the action of renewal of resources regarding reforestation, it is verified that only the factors were scored as neutral or positive. In the Aluízio Campos Complex, The Museum House and Light Farm, the activity of generation of seedlings for replanting is developed.

The activity of reforestation has limitations of climatic and soil order, it is considered that the sustainable forest management of the caatinga is the most suitable alternative for the Brazilian northeast. On the other hand, the quality of seedlings production requires a series of basic knowledge on the part of the producer, ranging from the harvest to the exit of the seedlings to the definitive site (SILVA, 2006). The advances related to reforestation, in degraded areas in the Caatinga, have been implemented with native forage species. In addition to the study of native species for sustainable management, other actions have been put into practice, such as: diffusion of seed bank formation, forage seedlings, protein bank, conservation in the form of hay and silage (NASCIMENTO et al., 2010).

\section{Geoprocessing system in the Aluízio Campos complex}

Regarding the use of orbital images of the TM/LANDSAT- 5 satellites, it is justified, since it made possible a better evaluation of the anthropic impacts of the studied area, which are very used in risk management studies. According to D'Antona et al. (2008) remote sensing is an instrument that must be used 
systematically in the improvement of interdisciplinary approaches, for studies of environmental changes and land cover.

A tool widely used in risk management studies, Geoprocessing also allows us to compare, through satellite images worked on special software such as ArcGis and Erdas, the integrity of an area's ambience through temporal and spatial comparison. In relation to the clarity and interpretation of the two images figure 3 , it was observed that the intervals used for the segmentation were the same, the IVAS (Soil Adjusted Vegetation Index), considering the values of 0.0 to 0.5 divided into four classes.

Comparing the images of figure 3 , whose temporal distance is equivalent to eighteen years, it is verified that environmental deterioration occurred, mainly in the area where the Aluízio Campos Complex is located, where the preservation established by the IVAS, characterized by the green color (highest value attributed) with only remnants of denser vegetation.

In the image of 1989 , the predominant values were in the range of 0.5 to 0.8 corresponding to a greater number of preserved areas, followed by values of 0.0 to 0.3 corresponding to the areas of bare soils and areas Constructed and the values 0.3 to 0.4 corresponding to the area in process of vegetation and soil degradation. It is also observed that the areas in blue color represent water.

With regard to the image for the year 2007, there is a greater predominance of the value of 0.0 to 0.3 corresponding to the areas of bare soils and built areas, attributed by the population growth of the city Campina Grande-PB, Visibly accentuated in the southwestern part of the map, which with this growth was associated with a greater withdrawal of natural resources from nature and major loss of ambience in areas that lack legal protection, aimed at conservation and preservation. Also, the southeastern part of the map, image of the year 2007, where the Aluízio Campos Complex is located, is predominantly yellowish, corresponding to a value of 0.3 to 0.4 . In this way, there is loss of preserved areas compared to the image of the year 1989. It is also worth noting that the predominance of the lime green color corresponds to a value of 0.4 to 0.5 .

Over the years the city of Campina Grande/PB, had its green areas devastated. The areas preserved in 1989 , when compared to 2007 , are noticeably larger (figure 3), it is noted that the removal of vegetation was in favor of the built areas. Thus, it can be said that with the reduction of green areas it contributes significantly to the reduction of water resources.

For Cardoso et al. (2010), the interpretation of satellite images enables an analysis of characteristics related to the occurrence of species in areas of interest for conservation and environmental preservation. Comparing the data of the present study with the application of vegetation indexes, Normalized Difference Vegetation Index (NDVI), Soil - Adjusted Vegetation Index (SAVI) and Foliar Area Index (IAF) in the characterization of the vegetative cover of the Northern region of Minas Gerais, Boratto et al. (2013) verified that the thematic maps of the images processed with the three indices studied allowed detecting and separating the vegetation cover in the studied region in different classes. It was observed that the SAVI index highlighted the influence of exposed soil, especially in the dry period. 


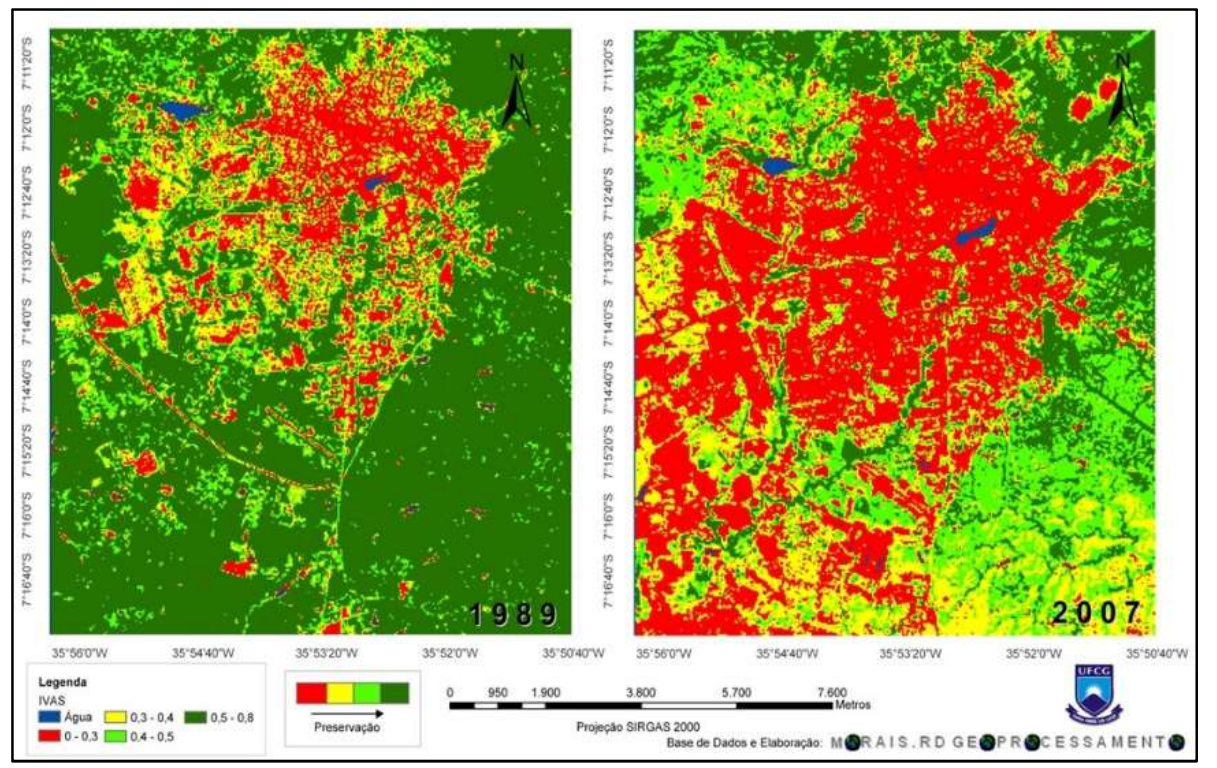

Figure 3: Map vegetation index, comparative of the city of Campina Grande/PB, with temporal cut of the years of 1989 and 2007.

The values obtained from the three indices studied (NDVI, SAVI and IAF) are directly related to the water availability of the soil profile. Therefore, the image of the wet period is more homogeneous and does not visually show areas with very low values of these three indices, which would characterize degraded areas, which are possible to be seen more clearly in the northern portion of dry period images. Finally, it is concluded that the use of the three vegetation indexes (NDVI, SAVI and IAF) are important tools for the management, characterization and use and occupation of the soil.

According to Marques (2006), the color is an element very used in the interpretation of colored images (in false color), in which the variations of the images are represented by different colors. In relation to a color image, the color of the object will depend on the amount of energy it reflects, the mixture between the colors (additive process), and the color associated with the original bands.

Comparing the use of geoprocessing techniques with the present study. To evaluate the environmental degradation of erosion or cumulative deposition of soil organic carbon (COS) in the Santana District, ljuí/RS, Bortolon et al. (2012) evaluated the spatial distribution of COS stocks through geoprocessing tools, which allowed a spatialized view of the impacts of changes in land use and management on CO and S stocks over time.

\section{Recommendations for better management of natural resources in the Aluízio Campos Complex}

The participatory and inclusive process is the best way to achieve a more homogeneous management of natural resources in the Aluízio Campos Complex (CAC). For the implementation of the Forest Garden, located in the southern part of the CAC, it is necessary to isolate this area, so that cattle and horses that are raised loose in the Complex do not affect the resilience of the area. Regarding the planting of seedlings in the Horto area should be done by native trees, and the participation and inclusion of the local community as well as the population is also suggested. In addition, a proposal of continuous environmental education, to raise awareness and awaken the sensibility of all, on the ecological, social and economic importance for Campina 
Grande/PB. For the recovery of the degraded area, it is suggested to use techniques aimed at the recovery of the area, in a shorter period.

Regarding the projects and constructions in the Aluízio Campos Complex, such as the gas pipeline, high voltage tower, highway, viaduct and railroad, there was no compensation and mitigation to the detriment of the installation of these projects, and it was verified that the nine residents residing in the CAC Were not benefited by the projects. On the contrary, with the withdrawal of natural resources such as vegetation and mineral resources, there was a reduction in the availability of these to residents; The introduction of domesticated animals (extensive husbandry), the soil became even more deteriorated and compacted.

For the installation of the Private Natural Heritage Reserve (RPPN), 100 hectares of the Aluízio Campos Complex were allocated, which is currently being approved by the State Environmental Agency. For an efficient management of resources in this area, the participation of social agents (community, CAC residents, academic environment, political participation) was also necessary to provide for the sustainability of the RPPN.

At first the physical isolation of the area is essential to provide its recovery, since, it is very deteriorated, with only vegetal remnants. About reforestation, the participatory community process should be by implementing nursery seedlings, seed collections and also, guaranteeing income for the employees directly involved in the process, exploiting the popular knowledge in this process is very important to achieve better efficiency.

Some measures are important for the recovery process of deteriorated areas in the Aluízio Campos Complex: soil recovery; restoration of the flora, with the construction of nurseries of endemic plants; isolation of the area through barbed wire fence; environmental education in the local community focused on environmental awareness; constant monitoring of activities; and educational campaigns. In order to raise public awareness and value the Aluízio Campos Complex, as a conservation area, very important, not only for its geographical location, but as an ecological refuge area for our fauna species, besides Of the phytotherapeutic importance of the species that are there.

\section{CONCLUSIONS}

In this way, it is affirmed that the Aluízio Campos Complex is an area with considerable geographical dimensions, which can contribute to the improvement of the quality of life of Campina Grande/PB and also concludes: according to the study, the environmental aspects of the Aluízio Campos Complex area can be characterized as: a broadly anthropogenic area, presenting several phytophysiognomies as a deactivated quarry area, an area with large vegetation remnants, a pasture area, an area undergoing recovery with coverage of secondary succession and areas with presence of human actions focused on economic development; Presence of bodies of water (barriers and dams) in the area.

Presence of isolated human dwellings and without basic sanitation, with absence of electric energy and treated water in the residences; Exploitation of flora and fauna resources by resident residents and 
bystanders; Even with anthropization, there was an expressive quantification of fauna resources, qualifying the ecological importance of the area with records of representatives of the most diverse zoological groups (mammals, reptiles, amphibians, birds and invertebrates).

The main anthropic impacts in the Aluízio Campos Complex were: land use for the implementation of high voltage and gas pipelines; Removal of soil and vegetables and scaring wildlife with the construction of BR-104 and the railroad; Compaction of the soil and non-viability of the natural recovery with trampling of the cattle and horses created in the area; Area used as quarry; Exploitation of fauna and flora.

\section{REFERENCES}

ALBUQUERQUE, H. N.; CERQUEIRA, J. S.. Ecologia em campo: fragmentos de aulas práticas e atividades de campo. Campina Grande: Impressos Adilson, 2013.

ALVES, J. J. A.; ARAÚJO, M. A.; NASCIMENTO, S. S.. Degradação da Caatinga: uma investigação ecogeográfica. Revista Caatinga, Mossoró, v.22, n.3, p.126-135, 2009.

ALVES, L. S.; ALBUQUERQUE, H. N.; BARBOSA, J. S.; AGUIAR, C. B.. Ações socioeducativas e ambientais no Complexo Aluízio Campos. Revista Brasileira de Informações Científicas, v.1, n.1, 2010.

ANDRADE, L. A.; FABRICANTE, J. R.; OLIVEIRA, F. X.. Impactos da invasão de Prosopis juliflora (sw.) DC. (Fabaceae) sobre o estrato arbustivo-arbóreo em áreas de Caatinga no Estado da Paraíba, Brasil. Acta Scientiarum Biological Sciences, Maringá, v.32, n.3, p.249-255, 2010. DOI: http://doi.org/10.4025/actascibiolsci.v32i3.4535

BENATTI, J. H.; MCGRATH, D. G.; OlIVEIRA, A. C. M.. Políticas públicas e manejo comunitário de recursos naturais na Amazônia. Ambiente \& Sociedade, v.6, n.2, p.74-89, 2003.

BORATTO, I. M. P.; GOMIDE, R. L. Aplicação dos índices de vegetação NDVI, SAVI e IAF na caracterização da cobertura vegetativa da região Norte de Minas Gerais. SIMPÓSIO BRASILEIRO DE SENSORIAMENTO REMOTO, 16. Anais. Foz do Iguaçu: INPE, 2013.

BORTOLON, E. S. O.; MIELNICZUK, J.; TORNQUIST, C. G.; LOPES, F.; GIASSON, E.; BERGAMASCHI, H.. Potencial de uso do modelo Century e SIG para avaliar o impacto da agricultura sobre estoques regionais de carbono orgânico do solo. Revista Brasileira de Ciências do Solo, v.36, p.831-849, 2012.

CARDOSO, C. A. L.; FARIA, F. S. R.. O uso do geoprocessamento na análise ambiental como subsídio para a indicação de áreas favoráveis a criação de unidade de conservação para o uso sustentável do minhocuçu Rhinodrilus alatus. E-Scientia, v.3, n.1, p.34-46, 2010.

CARVALHO, S. P.. Avaliação dos impactos ambientais no horto do Complexo Aluízio Campos. Monografia (Especialização em Desenvolvimento e Meio Ambiente) Centro Universitário de João Pessoa, João Pessoa, 2011.

CARVALHO, S. P.; ALBUQUERQUE, H. N.. Avaliação dos impactos ambientais no horto do Complexo Aluízio Campos. Revista Brasileira de Informações Científicas, v.2, n.2, p.116, 2011.
CAVALCANTI, N. B.; RESENDE, G. M.. Avaliação de barreiros e finalidade da água armazenada na região semiárida da Bahia. Revista Brasileira de Engenharia Agrícola e Ambiental, v.5, n.3, p.568-570, 2001.

CERQUEIRA, J. S.; SOUSA, E. N. A.; BARBOSA, J. S.. Os impactos negativos na fauna da fazenda Aluízio Campos. ENCONTRO DE BIOLOGIA, 5. Anais. Campina Grande: UNAVIDA, 2011

D'ANTONA, A. O.; CAK, A. D.; NASCIMENTO, T. T.. Integrando desenhos e imagens de satélite no estudo de mudanças no uso e cobertura da terra. Ambiente $\&$ sociedade, v.11, n.1, p.99-116, 2008.

DANTAS, C. S.; FERREIRA, O. M.. Erosões rurais origem e processos de evolução: estudo do caso da fazenda São Sebastião no município de São Luís de Montes Belos-GO. Goiânia: UCG, 2008.

EMBRAPA. Empresa Brasileira de Pesquisa Agropecuária. Solos do Estado da Paraíba. Brasília: EMPRAPA, 1972.

FALEIROS JÚNIOR, R. G.; BORGES, P. C. C.. A macrobioética e os direitos humanos: um caminho para o humanismo dialético. Revista de Bioética y Derecho, v.26, p.13-21, 2012.

FERREIRA, J. M. R.. Inventário da Ornitofauna em ambientes de Caatinga no Complexo Aluízio Campos em Campina Grande-PB. Campina Grande: UEPB, 2011.

FRACALANZA, A. P.; JACOB, A. M.; EÇA, R. F.. Justiça ambiental e práticas de governança da água. Ambiente \& Sociedade, v.16, n.1, p.19-38, 2013.

FRANCISCO, P. R. M.. Classificação e mapeamento das terras para mecanização agrícola do estado da Paraíba utilizando sistema de informações geográficas. Dissertação (Mestrado em Manejo de Solo e Água) - Universidade Federal da Paraíba, Areias, 2010.

GALHARTE, C. A.; CRESTANA, S.. Avaliação do impacto ambiental da integração lavoura-pecuária: aspecto conservação ambiental no cerrado. Revista Brasileira de Engenharia Agrícola e Ambiental, v.14, n.11, p.1202-1209, 2010.

ICMBIO. Instituto Chico Mendes. Sumário executivo do plano de ação nacional para a conservação das aves da Caatinga. Brasília: ICMBIO, 2011. 
JACOBI, P.. Sustentabilidade Ambiental, Consumo e Cidadania. Ambiente \& Sociedade, v.9, n. 1, p. 32-46, 2006. DOI: $\underline{\text { http://doi.org/10.1590/S1414-753X2006000100010 }}$

LEOPOLD, L. B.; CLARKE, F. E.; MANSHAW, B. B.; BALSLEY, J. R.. A procedure for evaluating environmental impacts. US Geological Survey circular, Washington, n.645, 1971.

LOPES, M. L.. Implantação de um parque urbano em Campina Grande: um plano urbanístico para o Complexo Aluízio Campos. Monografia (Especialização em Desenvolvimento e Meio Ambiente) - Centro Universitário de João Pessoa, João Pessoa, 2010.

MARQUES, W. R.. Interpretação de Imagens de Satélites em Estudos Ambientais. Ambiência, Guarapuava, v.2, n.2, p.281299. 2006.

MIGUEL, F. R. M.; VIEIRA, S. R.; GREGO, C. R.. Variabilidade espacial da infiltração de água em solo sob pastagem em função da intensidade de pisoteio. Pesquisa Agropecuária Brasileira, Brasília, v.44, n.11, p.1513-1519, 2009.

MUCELIN, C. A.; BELLINI, M.. Lixo e impactos ambientais perceptíveis no ecossistema urbano. Sociedade \& Natureza, Uberlândia, v.20, n.1, p.111-124, 2008.

NASCIMENTO, J. L. S.; COSTA, L. S. A.; XIMENES, L. J. F.. Atuação do Banco do Nordeste do Brasil em ciência e tecnologia na produção de caprinos e ovinos no nordeste do Brasil. Acta Veterinaria Brasilica, v.4, p.51-57, 2010. DOI: http://doi.org/10.21708/avb.2010.4.0.1839

NÓBREGA, C. C.. Análise de áreas verdes urbanas em Patos, Paraíba. Patos: UAEF, 2013.
RODRIGUES, V. F. A.; RODRIGUES, J. C.; NUNES, V. J.. Gestão ambiental em mineradora: Feira de Santana-BA. CONGRESSO BRASILEIRO DE GESTÃO AMBIENTAL, 4. Anais. Salvador: IBEAS, 2013.

SAMPAIO, R. S.; BRITO, P. C. R.. Impactos ambientais causados pela construção de rodovias. Salvador: UCSAL, 2009.

SÁNCHEZ, L. E.. Avaliação de impacto ambiental: conceitos e métodos. 2 ed. São Paulo: Oficina de Textos, 2013.

SANTOS, H. G.; JACOMINE, P. K. T.; ANJOS, L. H. C.; OLIVEIRA, V. A.; OLIVEIRA, J. B.; COELHO, M. R.; LUMBRERAS, J. F.; CUNHA, T. J. F.. Sistema brasileiro de classificação de solos. 2 ed. Rio de Janeiro: Embrapa Solos, 2006.

SILVA NETO, B.. Desenvolvimento sustentável: uma abordagem baseada em sistemas dissipativos. Ambiente \& Sociedade, v.11, n.1, p.15-31, 2008.

SILVA, L. B.. Variação na estrutura da madeira de quatro espécies da Caatinga nordestina e seu potencial para o desenvolvimento sustentável. Feira de Santana: UEFS, 2006.

SILVA, L. M. T.. Características da urbanização na Paraíba. Revista Cadernos do Logepa, v.3, n.5, p.12-25, 2004.

SINOKI, L. A.; LIMA, T. C. B. C.; COSTA, I. B.; FRANCISCO, O.. Levantamento sobre as propriedades terapêuticas de avelóz Euphorbia tirucallilinnaeus 1753 (malpighiales: euphorbiaceae) - Monografia (Graduação em Farmácia) Faculdades Integradas de Ourinhos, Ourinhos, 2011. 